\title{
Role of Plant Growth Hormones in Cashew: Key Strategy for Modifying Crop Performance
}

\author{
Babli Mog*, D. Adiga and M.G. Nayak \\ Directorate of Cashew Research, Puttur, D.K, Karnataka, India \\ *Corresponding author
}

Keywords

Cashew, Hormonal regulation, Low yield, Maximization of yield, Plant growth hormones

Article Info

Accepted:

10 June 2018

Available Online:

10 July 2018

\section{A B S T R A C T}

Cashew (Anacardium occidentale L.) is an important tropical nut crop of social and economic importance worldwide. World's total area under cashew cultivation is around $35100 \mathrm{~km}^{2}$. Despite the economic importance of cashew with increasing cultivation globally, the crop is threatened with the problems of low yield with world's average raw cashew nut yield is as low as $780 \mathrm{~kg} \mathrm{ha}^{-1}$. The present low productivity is due to establishment of plantation with seedling of non-descript origin, poor and irregular flowering, poor fruit set and premature fruit drop, low hermaphrodite flowers, inefficient pollination and nutritional deficiency etc. Plant growth hormones are gaining its importance for managing canopy, ensuring uniform flowering and enhancing fruit retention and yield under commercial cultivation for perennial fruit trees including cashew. Despite the importance of growth hormones to increase yield, their uses on cashew are limited despite daunting production challenges. In this review, we focus to understand how the endogenous hormones regulate the stages of plant growth in order to make exogenously applied plant growth hormones to play an important role in maximizing cashew nut yield. Although little works on effect of hormones existed in cashew, we show that cashew yield can be maximized through hormones by overcoming problems associated with plant growth, fruit set and final retention.

\section{Introduction}

Cashew (Anacardium occidentale L.) is an important tropical nut crop of social and economic importance worldwide. In current global scenario, major cashew production is concentrated in countries such as Vietnam, India, Nigeria, Brazil and Indonesia with annual raw nut production of $1,190,600 \mathrm{t}$, $665,000 \mathrm{t}, 660,000 \mathrm{t}, 147,629 \mathrm{t}$ and $122,000 \mathrm{t}$ respectively (FAO, 2008). World's total area under the cultivation of cashew is around
$35100 \mathrm{~km}^{2}$ with India sharing 20 percent and 16 percent of cashew area and production globally. Cashew is primarily grown for its kernel being highly nutritive and low cholesterol content. Other commercial and economic benefits of cashew include value added products such as juice, wine, vinegar, jam, pickle and cashew nut and shell liquid (CNSL) for industrial uses. In spite of economic importance of cashew as commodity and export oriented crop with increasing cultivation globally, world's 
average raw cashew nut yield is as low as 780 $\mathrm{kg} \mathrm{ha}^{-1}$ (FAO, 2008).

Cashew is an evergreen dicotyledonous woody tropical tree with medium canopy size. On an average the plant attains 5-8 m height. The leaves are alternate, simple, glabrous, oblong, leathery, often notched at the apex. The size of leaf varies from $6-24 \mathrm{~cm}$ in length and $4-15 \mathrm{~cm}$ in width based on species and variety. The root system of complete grown cashew tree consists of a taproot surrounded by a well developed and extensive network of lateral roots, $90 \%$ which lie on the $15-32 \mathrm{~cm}$ soil depth. The pattern of growth of cashew tree alternates with vegetative and reproductive phases. There are two types of branching in cashew intensive and extensive type (Damodaran, 1965). Intensive type of growth pattern tends to give bushy appearance to tree whereas extensive type results in spreading tree habit. Annually, two or three peak periods of growth are observed in bearing cashew tree with development of stray shoot growth. In bearing trees, from flower flush many shoots develop that give rise to terminal inflorescence/ panicle. The other vegetative flush gives rise to lateral shoots that develop soon after main crop has matured.

The cashew flowers are pentamerous, white or light green at the time of opening, later turn to pink. Two kinds of flowers viz. hermaphrodite (bisexual/perfect) and male (staminate) are present in the panicle. The perfect flowers are larger than staminate flowers (Damodaran et al., 1965). Cashew is considered as andromonoecious species due to presence of both male (staminate) and hermaphrodite (perfect) flowers in the same terminal panicle usually called as inflorescence of cashew. Number of panicles per plant, flowers per panicle and distribution of male and hermaphrodite flowers (sex ratio) in each panicle vary among varieties. In flowering panicle, abundance of male flowers is reported higher than perfect flowers. These results are consistent with findings from Rao and Hassan (1957); Bigger (1990) and Damodaran et al., (1966). The cashew produces abundant flowers but only less than 10 per cent of which are hermaphrodite, about 85 per cent of the hermaphrodite flowers are fertilized and only 4-6 per cent of them reach maturity to give fruits, the remaining shed away at different stages of development. The fruit drop in cashew during the early stages of development is attributed to physiological reasons (Nothwood, 1966). Immature fruit drop is one of major reason for reducing yield potential of cashew.

The formative effects of growth hormones is gaining its importance for managing canopy, ensuring uniform flowering and enhancing fruit retention and yield under commercial cultivation for perennial fruit trees including cashew (Olivier et al., 1990). The application of exogenous plant growth hormones has been reported to induce better root and shoot development, to break seed and bud dormancy and improve flowering and fruiting in many crop plants. Foliar spray of gibberellic acid and auxin increased shoot and root growth and total shoot and root biomass in treated cashew seedlings (Shanmugavelu, 1985). The better seed germination induced by GA in cashew has also been reported by Khan et al., (1957), Barton et al., (1957). Shanmugavelu et al., (1985) suggested that the seeds of tree species contained natural auxin which might probably regulate the seed germination. The use of cytokinin and auxin improved flowering and fruit set in mango (Chen, 1983) and cashew (Kumar, 1994). Therefore, growth hormones are gaining importance in cashew cultivation for overcoming problems associated with rooting, flowering, fruit set, fruit retention and poor yield. Hence, it is evident from studies that the economic importance of hormones is their ability to increase nut yield. There have been numerous reports considering increased 
yield due to the use of hormones especially in the horticultural sector but the use of plant growth regulators on cashew in particular is in its infancy. Hence, it is of the utmost importance to address this research gap and it is also essential to understand how the endogenous hormones affect or regulate the stages of plant growth in order to make exogenously applied plant growth hormones to play an important role in maximizing cashew nut yield. Here we discuss the influence of plant growth regulators on overall performance of cashew tree from available studies.

\section{Effects of plant growth hormones in Cashew}

\section{Dormancy and seed germination}

The most important functions of plant hormones are controlling and coordinating cell division, growth and differentiation (Hooley, 1994). Plant hormones can affect different plant activities including seed dormancy and germination. Seed germination and dormancy are important processes affecting plant overall performance. These processes are influenced by a range of factors, including plant hormones. The plant hormones, including ABA, IAA, cytokinins, ethylene, gibberellins and brassinosteroids, can positively or adversely affect seed germination, while interacting with each other. Germination rate (speed of germination) can be used as tool in breeding programme for evaluation of seedling vigor.

In cashew, Shanmugavelu et al., (1970) reported the effect of plant growth regulators on nut germination. Studies revealed that $\mathrm{GA}_{3}$ induced better nut germination in cashew than other chemicals. They suggested that nuts of cashew contained natural IAA which might probably regulate seed germination. They also reported that chlorophenoxy acetic acid
(CIPA) caused inhibition of germination which might be due to chemical interference with inherent auxin- kinin or auxingibberellins balance in seeds. Similar results were also reported by Laxmipathy et al., (2014) where studies revealed that application of $200 \mathrm{ppm} \mathrm{GA}_{3}$ was mainly attributed to enhanced germination, early seedling emergence, highest vigor index and better seedling growth in cashew. Oblisami et al., (1985) reported the influence of Azotobacter inoculants and growth regulators on seed germination in cashew. They found that maximum percentage of germination of the cashew nut was recorded in water soaked control $(92 \%)$ followed by Azotobacter plus GA (87\%). The treatments Azotobacter alone and IAA had same effect on germination.

\section{Regulation of seedling and root growth}

Cashew is highly heterozygous in nature due to cross pollination. Hence seedlings propagated through nuts exhibit wide genetic variation among cross pollinated progenies resulting in poor yield. Therefore, vegetative propagation offers opportunity in maintenance of desired characteristics of mother tree and hence it becomes the preferred choice for raising cashew propagules (Oliveria et al., 1989). In cashew, poor rooting of propagules is major concern which hampers usefulness of large scale cashew planting programme. The preliminary works done by Aliyu et al., (2007) showed that $65 \%$ air layered plants sprouted and less than $8 \%$ survived after transplanting. Further detailed studies by Aliyu et al., (2007) revealed that most of layers only callused and failed to root. These studies clearly indicate that root initiation is very poor in cashew layers.

Cashew is commercially propagated through soft wood grafting where early attainability of seedling height can reduce the cycle of propagation. Young seedlings of cashew 
usually do not produce lengthy tap root and secondary roots and hence seedlings suffer heavy causalities especially during summer. Among plant hormones, auxins have been reported to facilitate stem growth, adventitious root growth and activation of cambial cells (Went, 1934). Aliyu et al., (2010) reported that auxins significantly improved rooting in terms of layer take, number of roots per layer, number of days to rooting, root length and percentage of survival after transplanting. The possibility of inducing better root and shoot development by treating cashew seeds or seedlings with plant growth regulators to reduce mortality was also investigated by Shanmugavelu and Rangasawamy et al., (1970). They reported that $500 \mathrm{ppm}$ GA treatment resulted in $77 \%$ higher shoot growth but failed to induce root growth which were consistent with studies reported by Sumiki (1952) and Brain et al., (1955) reporting GA as negative regulator of root growth. Auxins like NAA at $100 \mathrm{ppm}$ and $500 \mathrm{ppm}$ recorded $92 \%$ higher root growth and production of secondary roots in cashew seedlings where as $\mathrm{GA}_{3}$ did not influence the production of secondary roots of cashew. Rao and Hassan (1957) reported that no lateral roots could be seen in case of one or two month old seedlings of cashew but studies by Shanmugavelu and Rangasawamy et al., (1970) showed the induction of roots when seed or seedlings are treated with plant growth regulators. GA treatments also resulted in increased shoot and root biomass in cashew seedlings focusing its role in cell elongation and increase in cell number (Brain et al., 1959). The most striking response of GA on cashew is the stem elongation. The number and length of cells in the cortex and pith regions were influenced by GA treatment. Therefore, it appears that stem elongation is predominantly due to cell elongation supplemented with cell division in the cortex and pith region which supports the work of Stowe and Tamaki (1957). In cashew increase in fresh and dry weight of shoots and roots can be attributed to increase in the overall assimilation and redistribution of materials within the plants.

Oblisami et al., (1985) studied the effect of Azotobacter and growth hormones on growth of cashew under pot culture experiment. They found that Azotobacter inoculants alone caused better growth of the root system and among the plant growth regulators GA induced better root growth over IAA. The better root formation by GA is in conformity with earlier works by Richardson, (1958) and Shanmugavelu, (1969) with different plant species. Better root growth of the cashew seedlings due to Azotobacter inoculants is in agreement with the earlier reports by Brown (1974). Combination of Azotobacter and GA induced better lateral root growth in early phases of plant development. This may be due to the fact that Azotobacter is known to synthesise growth promoting compounds like IAA, GA and GA like sunstances and releases into environment. This might be responsible for the better root development. Treatments combining Azotobacter with IAA and GA induced better shoot growth and this might be probably because of synthesis and excretion of IAA and GA in the root zone as reported by Brown, (1974) in various other crops.

\section{Propagation}

Cashew is a cross pollinated crop and therefore, the seedling progenies obtained through seed propagation are heterogeneous due to segregation. Conventional vegetative propagation methods such as air layering, mound strolling, or cutting have been attempted in cashew but the multiplication rate is inadequate to meet ever increasing requirement. However, the performance of this crop obtained through conventional vegetative propagation methods is poor and breeding desirable plant traits has also become difficult due to its out-breeding nature. Hence, 
in order to accelerate success in plant propagation, alternative propagation methods have been attempted and among them in vitro propagation is an effective method for large scale clonal multiplication of tree crops like cashew compared to conventional methods (Mott, 1981; Rao and Lee, 1982; Bajaj, 1986; Fiorino and Loreti, 1987; Mascarenhas and Muralidharan, 1989). Even though in vitro propagation method has been successfully attempted in other Anacardiaceae (Mango, Pictachio) (Litz et al., 1984; Martinelli, 1988), only limited success has been achieved in case of cashew (Philip, 1984; Jha, 1988; Lievens et al., 1989). Micro propagation method results in faster multiplication and building up the clonal stock of elite genotypes. In vitro propagation from mature plant tissues (nodal segments or shoot apices) was found difficult in cashew due to its recalcitrant nature, microbial contaminations and high phenolic content. Therefore, In vitro somatic embryogenesis potentially offers alternative forms of large scale propagation of plants. Yet attempt to induce somatic embryogenesis in cashew from immature embryos (Jha, 1988) and immature cotyledons (Hegde et al., 1994) met with limited success.

Types and concentrations of plant growth regulators used in culture media play crucial roles in the induction of in vitro organogenesis, because cashew is a hardrooter (D'Silva and D'Souza, 1992). Studies by Ananthakrishnan et al., (1999) reported induction of somatic embryogenesis from nucellus-derived callus of cashew when supplemented with $4.52 \mathrm{mM}$ 2,4-D. Further studies on the ontogeny of somatic embryos showed that the cells destined to become somatic embryos divided into spherical or filamentous pro-embryos. Subsequent divisions in the pro-embryo led to globular, heart and torpedo stages of somatic embryos. There was no further development of the torpedo stage in the liquid medium containing
2,4-D. Bavatharine et al., (2010) confirmed the development of somatic embryoids directly from cultured cotyledon explants when cultured on MS basal medium containing various concentrations (0-10 $\mathrm{mg} /$ litre) of BAP (benzyl amino purine). MS medium with $8 \mathrm{mg} /$ litre BAP was the most optimal concentration for the induction of somatic embryos among tested. Studies by Kamshananthi et al., (2012) reported $80 \%$ higher nodule induction in cotyledon explants in MS medium with $2 \mathrm{mg} /$ litre of BAP and $40 \%$ higher root formation with $2 \mathrm{mg} / \mathrm{litre}$ Kinetin and NAA (Naphthalene acetic acid). Further, it was also noticed that medium which contained 2mg/ litre BAP showed higher percent of somatic embryoid formation directly from cotyledon explants. In addition, Thimmappaiah et al., (2002) noticed that a repeatable auxillary shoot bud induction in cashew was obtained on MS medium with $2.74 \mathrm{mM}$ L-glutamine, $87.6 \mathrm{mM}$ sucrose containing thidiazuron (TDZ) alone and in combination with BA (benzyl adenine). TDZ at $0.45 \mu \mathrm{M}$ was best for auxillary shoot bud proliferation (4.5 buds per shoot) with maximum response $(100 \%)$. Further it was found that in vitro rooting on auxin media and pulsing micro shoots in $10 \mathrm{mM}$ NAA was ineffective.

\section{Control of plant growth}

The improvements in over all plant performance including plant productivity are largely dependent on manipulation of physiological mechanisms by chemical means. Trees and shrubs often grow too large for the available space. In the past, costly mechanical trimming was the sole method available to reduce tree and shrub size. Consequently, chemical growth retardants were developed as an inexpensive approach to limit size and the growth rate of trees. Cashew is a fast growing woody perennial, covers the allotted space under high density planting, within a short 
span of 6-7 years. Controlling excessive vegetative growth for increased or sustained productivity is the major principle of high density planting (Santram, 1996). In cashew, due to non availability of dwarf clones, dwarfing root stocks or a pruning technology for the management of vigorous canopies, use of growth retarding chemicals assumes significance. The first major breakthrough in the commercial feasibility of tree growth retardants (TGRs) on a large scale was the formulation in the late $1970 \mathrm{~s}$ of the cell elongation inhibitors, paclobutrazol, uniconazole, and flurprimidol for trunk injection. Paclobutrazol is more potent than most other growth retardants and relatively low rates are required to inhibit shoot growth. The most pronounced effect of paclobutrazol on plant is the reduction in height, with the treated plant being greener and more compact. The plant becomes greener due to increased chlorophyll content per unit leaf area.

Reduction in shoot growth by Paclobutrazol (PBZ) occurs primarily as a consequence of reduced internode elongation. Treatments with like Paclobutrazol was found effective in reducing the growth of fruit crops like pear, peach, lemon, apple, litchi, apricot, plum and mango. Misra and Singh, (1991) found that reduction in growth was observed in cashew when Paclobutrazol was applied to young grafted plants at nursery stage. Application of $50 \mathrm{ppm}$ PBZ as soil drench could restrict vegetative growth up to six months. The growth of tap root was reduced while lateral root growth was increased. Treated cashew grafts when planted in field showed normal growth. Studies conducted by $\mathrm{R} \mathrm{K}$ Meena et al., (2014) reported the regulation of growth and yield of cashew varieties by PBZ application when applied @ 1,2 and 3 a.i. per plant as soil drench. They found that the application of PBZ reduced plant height, canopy spread and intermodal length. The application of PBZ at pre-flushing stage was effective in increasing number of flushes with yield increment up to $51.78 \%$.

\section{Influence on leaf area and photosynthesis}

Among various determinants of crop yield, plant leaf area plays significant role in influencing light interception, transpiration, photosynthesis and plant productivity (Goudriaan and Van Laar, 1994). In cashew, the fruit set and development is dependent on irradiance and the adaption of leaf to shade is minimum (Subbaiah, 1984). Lakshmipathi et al., (2014) reported that application of $\mathrm{GA}_{3} @$ 50 ppm and Ethrel @ 50 ppm recorded maximum leaf area. Similar kind of results was also reported by Wahdan et al., (2011) in mango. This increase in leaf area with $\mathrm{GA}_{3}$ might be related to the fact that GA promote leaf area through the increase of cell division in higher plant (Hartmann et al., 2002; Hopkins and Huner, 2004; Harris et al., 2004). Higher leaf area values recorded with Ethrel and $\mathrm{GA}_{3}$ may be due to increased concentrations of photosynthesis in the shoot (Nunez et al., 1998; Zofoli et al., 2009 and Zahoor et al., 2011) as reported in grape.

In agricultural crop system, any breakthrough in productivity has to come by improving the physiological efficiency of the plants in terms of photosynthesis, partitioning of photoassimilates, improved biophysical characteristics and several other metabolic reactions, which are linked by numerous interactions ultimately leading to productivity. Plant growth regulators have been shown to influence these processes in one way or the other. Lakshmipathi et al., (2014) reported that exogenous application of $\mathrm{GA}_{3} @ 50$ ppm and Ethrel @50 ppm recorded maximum net photosynthetic rate $\left(\mathrm{P}_{\mathrm{N}}\right)$ and stomatal conductance $\left(\mathrm{g}_{\mathrm{s}}\right)$ in cashew. They also reported that timings and quadrants of the canopy had significant influence on photosynthetic rate and stomatal conductance. 
These findings were consistent with Farquhar and Sharkey, (1982) who reported that at low $\mathrm{PAR}$, the $\mathrm{P}_{\mathrm{N}}$ is reduced and stomata partly closed, impose less limitation on $\mathrm{P}_{\mathrm{N}}$ (Caemmerer and Farquhar, 1981). Studies on exogenous application of plant growth regulators on photosynthetic activity of cashew varieties indicated that PAR and LA are positively correlated with yield indicating their importance in yield enhancement in cashew (Lakshmipathi et al., 2014).

\section{Sex ratio, flowering and fruiting}

Flowering in cashew is seasonal and produces innumerable flowers but only 1-2 per cent of the flowers set fruit and reach maturity. Production of more number of pistillate flowers and reduction in nut drop can be accomplished by the use of plant hormones. It has been reported that foliar sprays of Gibberellic acid $\left(\mathrm{GA}_{3}\right)$, 1- Naphthalene acetic acid (NAA) and Ethylene increased the production of perfect flowers and improved sex ratio in cashew (Puhual et al., 1993; Kumar et al., 1995; Aliyu et al., 2011). Gawankar et al., (2010) opined that cashew trees sprayed with $50 \mathrm{ppm}$ Ethrel had significantly the highest number of flowering panicles per square, number of perfect flowers per panicle and sex ratio. Ethylene is believed to be the chemical which causes natural initiation of flowering. It can also be attributed to an increase in the activity of peroxidase and $\alpha$-amylase which ultimately released more sugar for induction of flowering (Yamdagni and Khangia, 1989). A significant increase in the number of flowering panicles per square meter with Ethrel 50 ppm in case of Bhaskara was reported by Lakshmipathi et al., (2014). They also reported improvement in sex ratio by foliar application of Ethrel at pre- bloom stage. Gawankar et al., (2010) indicated that the number of staminate flowers was related to the number of lateral per square meter. Higher number of laterals in water sprayed trees could have resulted in higher number of staminate flowers. Singh et al., (1992) reported that foliar application of Ethrel @ 100 ppm increased the number of perfect flowers in cashew.

Improvement in the sex ratio with the application of Ethrel was mainly due to increased number of perfect flowers. Ethrel may also have exerted its effect on sex expression by manipulating endogenous auxin levels corresponding to a reduction in staminate flowers as reported by Mariappan et al., (1995). Kumar et al., (1996) reported that number of perfect flowers per panicle was positively correlated with yield in cashew. A similar correlation was observed by Lenka $e t$ al., (2001). Dorajeerao et al., (2001) reported that clones having broader sex ration were high yielder.

Fruit set and their retention are the major limiting factors for low yield in cashew which needs due attention. The nuts that develop after pollination start drying followed by dropping, leading to very low percentage of matured nuts. Use of growth regulators like auxins, gibberellins, and ethylene has resulted in improving the vegetative and reproductive parameters which are associated with high yield in many fruit crops (Lafer, 2008; Chacko et al., 1974; Rawash et al., 1983; Singh et al., 1986). Preliminary studies carried out on improvement of sex ratio, fruit set, fruit retention and yield by use of growth regulators have indicated beneficial effects in cashew. Increase in the percentage of fruit set by 55 per cent in cashew with foliar application of 10 ppm NAA was reported by Murthy et al., (1975). Lashmipathy et al., (2014) reported that spraying of $50 \mathrm{ppm}$ Ethrel increased the number of fruits set, number of fruits retained per panicle, nut weight $(\mathrm{g})$, nut yield $(\mathrm{kg})$ per tree and reduced fruit drop per panicle in cashew. Increased fruit set and fruit retention due to application of Ethrel and other growth regulators could be attributed to the increased number of bisexual flowers and reduced pre 
mature fruit drop. Similar findings were also reported by Singh et al., (1986) in mango. Fruit drop, an abscission phenomenon, often occurs due to auxin deficiency in growing fruits and could be prevented by the exogenous application of synthetic auxins such as NAA and 2,4-D. Reduced fruit drop due to exogenous applications of growth regulators may be attributed to increased endogenous auxins which helps in overcoming the formation of abscission layer in the abscission zone, thereby reducing the immature fruit drop and increasing mobilization of nutrients to the developing fruit (Salisbury and Ross, 1986; Kumar et al., 1994). Reduced fruit drop in cashew due to application of growth regulators was also reported by Konhar and Arun Mech, (1988). Aliyu et al., (2011) found that highest fruit set and improvement in fruit retention was recorded from twigs treated with $\mathrm{GA}_{3}$.

This remarkable response in cashew twigs treated with $\mathrm{GA}_{3}$ over other exogenous hormones suggests hormone-specific nature of cashew tree (Davenport, 2003). But it was surprising that none of treated twigs successfully retained $100 \%$ of fruit set despite improvement in fruit retention ability of the treated twigs. This observation corroborated studies on the complexity of factors controlling yield and role of nutrition to fruit development and retention in cashew (Aliyu, 2008). Such studies correspond to role of $\mathrm{GA}_{3}$ to enhance photosynthetic production through an efficient use of nitrogen $\mathrm{N}$ (Khan et al., 2004). Thus it is evident that upper limit regulatory mechanism and compensatory effect of the number of fruits vs. weight of fruit per tree will continue to play a significant role in cashew tree productivity (Aliyu, 2011).

\section{Influence on nut yield}

Correlation analysis for yield attributing characters using different plant parameters has been attempted by several workers. Nut yield (kg) per tree was found to be most significantly and positively correlated with number of flowering laterals per square meter, total number of laterals per square meter, duration of male flowers, duration of hermaphrodite flowers, number of male flowers per panicle, number of hermaphrodite flowers per panicle, total number of flowers, number of fruits set per panicle, number of fruits retention per panicle and nut weight (Lashmipathy et al., 2014 and Kumar et al., 1996). Similar correlation was also reported by Lenka et al., (2001).

Among the various factors influencing cashew yield, the narrow sex ratio is of primary importance. Therefore, growth regulators are gaining importance in cashew cultivation for overcoming problems associated with fruit set, development and, final retention. Improvement in sex ratio with application of growth regulators was mainly due to increased number of bisexual flowers. Both auxin and ethrel had stimulating effect on the physiological changes in the tissues influencing the flowering characters (Salisbury and Ross, 1986). The increase in length and number of secondary branches per panicle are important attributes for the production of more number of flowers which increases the yield. The flowering in other fruit crop as influenced by ethrel and auxin was also reported by Chacko et al., (1974) and Rawash et al., (1983) in mango. Increased nut yield by Ethrel application has been reported in cashew by Mohan and Rao, (1995); Gajbhiye et al., (2007); Gawankar et al., (2010) and Lashmipathy et al., (2014). Increased nut yield with application of growth regulators could be attributed to increased number of bisexual flowers, fruit set, fruit retention and total number of nuts per tree (Veeraragha vathatham and Palaniswamy, 1983). Aliyu et al., (2011) showed that application of exogenous hormones can 
improve fruiting/yield significantly through the flowering components (Days to flowering and Hermaphrodite flowers per panicle) in cashew. Kurian and Iyer (1993) reported similar yield increase through intense flowering in mango trees sprayed with cytokinin-based plant growth regulators. The significant reduction in the period of flowering will considerably enhance flowering synchronization in cashew. These two events coupled with the increased number of hermaphrodite flowers were likely responsible for higher fruit set through improved pollination.

PBZ has been reported to exert influence on partioning the photosynthates to the sites of flowering and fruit production consequent to the reduction of vegetative growth. In this context, Meena et al., (2014) reported that PBZ treatment increased nut yield per plant but nut length, width, weight and volume decreased. The maximum yield increment of treated plants $(51.7 \%)$ was associated with PBZ @ 2.0 a.i. per plant. A significantly higher fruit set and fruit retention in PBZ treated plants had favourable impact on culminating higher nut yield per plant.

\section{Influence on nutritional value}

Cashew is of considerable economic importance due to various economic uses of its components. Cashew apple is used as an important ingredient in the production of cashew beverages while cashew kernel is of high food value with $40-57 \%$ oil and $20 \%$ protein content. Studies on the influence of plant growth regulators and nutrients on nutritional quality in cashew are meagre and limited. However, published studies indicated that the application of PGR and nutrients had marked influence on apple weight, quality, yield and juice content of the cashew apple. Kumar et al., (1996) studied the effects of different levels of NPK nutrients and plant growth regulators on apple quality and yield in cashew varieties. They found that combined application of ethrel @50 ppm and 500: 250: $250 \mathrm{~g} \mathrm{NPK/plant/year} \mathrm{was} \mathrm{most} \mathrm{effective}$ treatment. The combined application showed decrease in weight and juice content of apple which might be due to increase in the number of fruits per panicle. There was considerable increase in total soluble solids and apple yield which might be attributed to the positive interaction between growth regulators and nutrients.

Gibberellins are known to influence certain environmental factors for flowering in large number of plant species (Krishnamurthy, 1975). Exogenous application of $\mathrm{GA}_{3}$ in plant species resulted in increase in fruit set and decrease in fruit drop resulting in higher yields (Moore et al., 1975; Valdovinos, 1975). Murthy et al., (1975) on the other hand found that $\mathrm{GA}_{3}$ has little effect on cashew. There have been studies of the levels of $\mathrm{GA}_{3}$ and seed development in different plants (Skene $e t$ al., 1961; Ogawa, 1963) but there is scanty information on the $\mathrm{GA}_{3}$ induced changes of free amino acid and total protein during development of cashew kernel.

M. Hariharan et al., (1979) studied the free amino acid and total protein content in three developing stages of kernel in cashew after foliar treatment with $40 \mathrm{ppm}$ and $50 \mathrm{ppm}$ gibberellic acid. They found that the effects of $\mathrm{GA}_{3}$ on free amino acid and protein content vary according to concentrations of hormone used but does not follow uniform pattern. In $\mathrm{GA}_{3}$ treated cashew kernels, the amino acid contents show progressive decrease with the growth and maturation of the nut and greater accumulation of protein. Cystein which is absent in the control samples at all stages, is abundant in the treated samples. But hydroxyl proline content was completely disappeared in 
treated samples. Treatment with $\mathrm{GA}_{3}$ results in a marked increase in protein content of kernel at all stages of development. The onset of marked storage protein synthesis commences in the early phase itself under the influence of $\mathrm{GA}_{3}$ treatment in contrast to control.

Hence concluded that the ways in which plants transport and regulate both local and long distance hormone based signals are important research targets. Similarly, the mechanisms by which these signals are translated into plant responses such as changes in plant architecture and biomass, changes in plant water transport, gas exchange and yield related parameters need extensive studies to understand the complexity between hormonal balance and plant performance. Such knowledge can impart greater influence on screening cashew varieties with desired agronomic and plant traits and can allow the development of novel ways of managing cashew trees in the field. The research in this direction is important in the context of food security because the traditional or conventional breeding for yield trait is both slow and complex. However, determining the important phenotypic trait that could act as yield surrogate for yield requires in depth knowledge.

Plant architecture, reproduction capacity and tolerance to various abiotic stresses are among the agronomically important traits controlled by plant growth hormones. Given the importance of growth hormones in these processes, engineering their biosynthetic and signaling pathways offer wide potentials for enhancing yield in cashew. To date, information on plant growth hormone signaling and pathways in perennial trees like cashew is scarce. Therefore, the potential exists to identify hormone regulated mutants or transgenics with improved productivity in perennial fruit crops like cashew.
Plant growth hormones affect nut yield and nutritional qualities. The seed and nutritional qualities also constitute important traits that need consideration. Whereas, there is evidence of positive health benefits by cashew nut and its value added products, the impact of endogenous plant growth hormones on nutritional qualities of nuts and cashew apple has to be determined. Preliminary studies indicate influence of growth hormones on nutritional qualities of cashew apple and its value added products, yet detailed comprehensive studies on improving quality of cashew apple, cashew nut and various value added products through hormonal manipulation is highly desirable for future agro-biotechnological and nutraceutial application.

\section{Acknowledgements}

The authors acknowledge the financial support in part by the Directorate of Cashew Research, Puttur under the Department of Crop Management section and Indian Council of Agricultural Research.

\section{References}

Aliyu, O.M., Adeigbe, O., Awopetu, J.A., Foliar application of exogenous plant hormones at pre blooming stage improves flowering and fruiting in cashew (Anacardium occidentale L.), J. of Crop Sci. and Biotechnol. 14 (2) (2011) 143-150

Aliyu, O.M., Clonal propagation in cashew (Anacardium occidentale): effect of rooting media on the rootability and sprouting of air-layers, Tropical Sci. 47(2) (2007) 65-72

Aliyu, O.M., Compatibility and fruit-set in cashew (Anacardium occidentale L.), Euphytica 160 (2008) 25-33

Aliyu, O.M., Dada, K.E., Hammed, L.A., Can auxins improve rooting of propagules 
and establishment of cashew clones? Fruits 65 (2010) 307-314

Ananthakrishnan, G., Ravikumar, R., Prem Anand, R., Vengadesan, G., Ganapathi, A., Induction of somatic embryogenesis from nucellus-derived callus of Anacardium occidentale L. Scientia Horticulturae 79 (1999) 91-99

Bajaj, Y.P.S.,Biotechnology of tree improvement for rapid propagation and biomass energy production, Biotechnology in Agriculture and Forestry 1, Trees I, Springer Verlag, Berlin, Germany, (1986) pp. $1 \pm 23$

Bavatharine, G., Thayamini, H.S., In Vitro response of cotyledon explants of cashew (Anacardium occidentale L.) cultured in different concentrations of BAP, Department of Crop Science, Faculty of Agriculture, Eastern University, (2010) Chenkalady, Sri Lnka

Bigger, M., Selenothrips rubrocinctus (Grand) and the floral biology of cashew in Tanganyika, East African Agri. J. 25 (1990) 229-234

Brian, P W., Chester E V., Curtis, P J., Hemming, H G., Catherena, H., Gibberellic acid, a metabolic product of the fungus Gibberella fugikorai: some observations on the production and isolation, J. Sci. Fd. Agric. 6 (1955) 340-348

Brian, P W., Effects of gibberellins on plant growth and development, Biol. Rev. 34 (1959) 37-84

Brown, M D., Seed and root bacterization, Ann. Rev. Phytopath. 12 (1974) 181197

Caemmerer, S.V., Farquhar, G.D., Some relationships between the biochemistry of photosynthesis and the gas exchange of leaves, Planta. 153 (1981)376-387

Chacko, E.K., Kohli, R.R., Randhawa, G.S., Investigation on the use of 2- chloroethyl phosphoric acid (ethephon, CEPA) for control of biennial bearing in mango, Scientia Horticulturae 2 (1974) 389-398

Chen, W.S., Cytokinins of the developing mango fruit, Plant Physiol. 71 (1983) 356-362

D'Silva I., D'Souza L., In vitro propagation of (Anacardium occidentale L.), Plant Cell Tissue Organ Cult. 29 (1992) 1-6

Damodaran, V.K., Abraham, J., Alexander, K.M., The morphology and biology of the cashew flower I-Flowering habit, flowering season, morphology of the flower and sex ratio, Agricultural Research Journal of Kerala 3(1\&2) (1965) 23-28

Davenport, T.L., Pearce, D.W., Rood, S.B., Correlation of endogenous gibberellic acid with initiation of mango shoots growth, J. of Plant Growth Regul. 20 (2003) 308-315

Dorajeerao, A.V.D., Ravishankar, C., Reddy, M.L.N., Influence of flowering phase on nut yield of different cashew clones, J. of Plantation Crops 25 (2001) 55-60

FAO., Food and Agriculture Organization of the United Nations, Crop Production Statistics Division (2008)

Farquhar, G.D., Sharkey, T.D., Stomatal conductance and photosynthesis, Annu. Rev. Plant Physiol. 33 (1982) 317-326

Fiorino, P., Loreti, F., Propagation of fruit tress by tissue culture in Italy, Horti. Sci. 22 (1987) 353 4358

Gajbhiye, R C., Jalgaonkar, V N., Bendale, V W., Gawankar, M S., Effect of growth regulators to improve fruit set and yield in cashew, National Seminar on Research, Development and Marketing of Cashew. In: Souvenir and extended summaries, ICAR Research Complex for Goa, 20-21 ${ }^{\text {st }}$ November (2007) pp. 136-137 
Gawankar, MS., Sawale, RD., Pawar, SN., Chavan, SA., Effect of Ethrel on flowering, sex-expression and yield in cashew, J. of Hort. Sci. 5 (1) (2010) 68-70

Goudriaan, J., Van Laar, H. H., Modelling potential crop growth processes, Kluwer Academic Publishers (1994) Dordrecht, The Netherlands

Harris, R. W., Clark, J. R., Matheny, N. P., Arboriculture integrated management of landscape trees, shrubs and vines (4th edition), (2004) Prentice Hall, Upper Saddle, New Jersey

Hartmann, H.T., Kester, D.E., Davies F. T., Geneve, R. L., Plant Propagation Principles and Practices (7th edition), (2002) Prentice Hall, Upper Saddle River, New Jersey

Hegde, M., Kulasekaran, M., Jayasanker, S., Shunmugavelu, K.G., In vitro embryogenesis in cashew (Anacardium occidentale L.), Indian Cashew J. 20 (1994) 17-25

Hooley, R., Gibberellins: perception, transduction and responses, Plant Mol Biol. 26 (1994) 1529-1555

Hopkins, W. G., Huner, N. P. A., Introduction to Plant Physiology (3rd Edition), John Wiely and Sons Inc, (2004) USA

Jha, T.B., In vitro morphogenesis in cashew nut (Anacardium occidentale L.), Indian J. Exp. Biol. 26 (1988) 505-507

Kamashananthi, T., Thayamini, H., Induction of somatic embryogenesis from cotyledon explants of cashew (Anacardium occidentale L.), J. of Agril. Tech., 8(6) (2012) 2089-2099

Khan, A., Gross, J.A., Smith, D.E., Effect of gibberellins on germination of lettuce seed, Science 125 (1957) 645-646

Khan, N.A., Mobin, M., Samiullah, M., The influence of gibberellic acid and sulfur fertilization rate on growth and S-use efficiency of mustard (Brassica juncea), Plant Soil 270 (2004) 269-
274

Konhar, T., Arun, M., Effects of growth regulators on flowering, fruit set and fruit retention in cashew (Anacardium occidentale L.), Indian Cashew J. 18 (1988) 17-19

Krishnamoorthy, H.N., Gibberellins and Plant Growth, (1975) Wiley, New Delhi

Kumar, D. P., Khan, M. M., Melanta, K. R., Effect of nutrition and growth regulators on apple characters and yield in cashew (Anacardium occidentale L.), The Cashew 10 (2) (1996) 17-24

Kumar, D.P., Khan, M.M., Melanta, K.R., Effect of growth regulators on sex expression, fruit set, fruit retention and yield of cashew, In: Proceedings of the PLACROSYM XI, 30 November - 3 December (1994), Calicut, Kerala, India. pp. 610-627

Kumar, D.P., Khan, M.M., Venkataramu, M.N., Effect of NPK and Growth Regulators on harvesting nut yield, shelling percentage and kernel grade of cashew (Anacardium occidentale L.), J. of Plantation Crops 23 (2) (1995) 96-104

Kurian, R.M., Iyer, C.PA., Chemical regulation of tree size in mango (Mangifera indica L.) cv. Alphonso. III. Effects of growth retardants on yield and quality of fruits, J. Hort. Sci. 68 (1993) 361-364

Lafer, G., Effects of different bioregulator applicatiobs on fruit set, yield and fruit quality of Williams pears, Acta Horticulturae (2008) 800p

Lakshmipathi., Dinakara, A.J., Kalaivanan, D., Mohana, G S., Ramkesh, M., Effect of plant growth regulators, quadrants and time of the day on photosynthetic activity in cashew (Anacardium occidentale L.) Var. Bhaskara, Ecol. Env. Cons.20 (2014) $1-4$ 
Lakshmipathi., Dinakara, A.J., Kalaivanan, D., Mohana, GS., Ramkesh, M., (2014) Effect of growth regulators on leaf area and yield of cashew (Anacardium occidentale L.) Var. Bhaskara, Ecol. Env. Cons. 20 (2014) 9-11

Lakshmipathi., J., Dinakara, A., Kalaivanan, D., Influence of growth regulators on certain reproductive parameters of cashew (Anacardium occidentale L.) variety Bhaskara, J. of Plantation Crops 42(1) (2014) 113-116

Lenka, P.C., Mohapatra, K.C., Dash, S., Mishra, N.K., Genetic variability and character association in cashew (Anacardium occidentale L.) Horticultural J. 14 (2) (2001) 105-110

Lievens, C., Pylyser, M., Boxus, P., Clonal propagation of Anacardium occidentale by tissue culture, Fruits 44 (1989) 553-557

Litz, R.E., Knight, R.J., Gazit, S., 1984 In vitro somatic embryogenesis from Mangifera indica L. Callus, Scientia Horticulturae 22 (1984) 233-240

Mariappan, S., Prabakaran, J., Sambandamoorthy, S., Effect of growth regulators on sex expression and fruit set in cashew (Anacardium occidentale L.), The Cashew 9(1) (1995) 11-13

Martinelli, A., Use of in vitro techniques for selection and cloning of different Pistacia species, Acta Horti. 227 (1988) 436- 437

Mascarenhas, A.F., Muralidharan, E.M., Tissue culture of Forest tress in India, Curr. Sci. 58 (1989) 606 \pm 612

Meena, R. K., Adiga, J. D., Nayak, M. G., Saroj, P. L., Kalaivanan, D., Effect of paclobutrazol on growth and yield of cashew (Anacardium occidentale L.), Vegetos 27 (2014) 11-6

Misra, L P., Singh, R., Effect of paclobutrazol on cashew grafts in nursery, Indian J. of Plant Physiol. 34(1) (1991) 102-105

Mohan, E., Rao, M M., Effect of growth regulators and pruning on the growth and yield of cashew, Environ. Eco. 13 (1995) 675-679

Moore, T.C., Ecklund, P. R., In: Gibberellins and Plant Growth. (Ed Krishnamoorthy, H N), (1975) Wiley, New Delhi

Mott, R.L., Cloning Agricultural Plants via in vitro techniques, In: Conger, B.V. (Ed.), CRC Press, Boca Raton, FL, (1981) pp. $217 \pm 254$

Murthy, K.N., Kumaran. P.M., Nayar, N.M., Increasing fruit set in cashew by hormone spraying, J. of Plantation Crops 3 (1975) 81-82

Nothwood, P.J., Some observations on the flowering and fruit-setting in the cashew (Anacardium occidentale L.), Tropical Agriculture (Trin.) 43 (1966) 35-42

Nunez, M., Musa, J.L., Alfonso, J.L., Coll, F., The influence of two new Cuban Bioregulators on plant yield ofonion(Allium cepa) cv. 'Red Creole, Cultivas Trop. 19 (1998) 21-24

Oblisami, G., Santhanakrishnan, P., Pappaiah, C.M., Shanmugavelu, K.G., Effect of Azotobacter inoculant and growth regulators on the growth of cashew, Acta Hort. 108 (1985) 40-45

Ogawa, Y., Gibberellin like substances occurring in the seeds of Pharabitis nilchois and their change in contents during seed development, Plant and Cell Physiol. 4 (1963) 217-225

Oliveira, E.T., Propagacao vegetative de Pinus sp. Via cultura de tecido, Sao Paulo Univ. / ESALQ, Diss., (1989) Piracicaba, Sao Paulo, Brazil.

Olivier, O.J., Jacobs, G., Strydom, D. K., Effect of a foliar application of paclobutrazol in autumn on the reproductive development of 'Songold' plum, South African J. of 
Plant and Soil 7 (1990) 92-5

Phillip, V.J., Unni, P.N., In vitro propagation of cashew crop improvement. In: Bhaskara Rao EVV, Khan HH (eds.), Cashew Research and Development CPCRI, Kasargod (1984) pp. 77-82

Puhual, S., Bunchongsiri, S., Booranasawettathrum, S., Effect of plant growth regulators on sex expression of cashew nut, Tenth Rajamangala Institute of Technology Seminar on Agricultural Science, (1993) Lampang (Thailand)

Rao, A.N., Lee, S.K., Importance of tissue culture in tree propagation. In: Fujiwara, A. (Ed.), Proceedings of the 5th International Congress on Plant Tissue Cell Culture, Maruzan, Tokyo, Japan (1982) pp. 715 \pm 718

Rao, V. N. M., Rao, I K S., Hassan, M., Studies on seed viability in cashew, Ind. J. Agric. Sci. 27 (1957) 289-294

Rawash, M.A., El-Hammady, A., El-Nabawy S., Khalifa, A.S., El-Massy, H., Regulation of flowering and fruiting in mango trees by using some growth regulators, Annals of Agril. Sci. 28(11) (1983) 227-240

Richardson, D., Radical elongation of Pseudotsuga menziesii in relation to light and gibberellic acid, Nature 181 (1958) 429-430

Salisbury, F.B., Ross, C.W., Plant Physiology (Third edition). Wadsworth Publishing Company, Belmont, California, USA (1986) pp. 309-349

Santram., High density orcharding, Mango Res. (1996) Bull No 122

Shanmugavelu, K. G., Effect of gibberellic acid on seed germination and development of seedlings of some tree plant species, Madras Agril. J. 55 (1970) 311-314

Shanmugavelu, K. G., Studies on some aspects of physiological action of gibberellic acid on some tree plant species, South Indian Hort. 13 (1969) 62-70

Shanmugavelu, K.G., Rangaswamy, G., A chromatographic survey of naturally occurring auxins in some tree plant species, Auara. 2 (1970) 36-44

Shanmugavelu, K.G., Studies on the effect of plant growth regulators in cashew, Acta Horticulturae 108 (1985) 35-43

Singh, M., Choudhary, A.S., Prasad, M.A., A note on effect of some plant growth regulators on fruit retention in Mangifera indica L. Haryana J. of Horti. Sci. 15(3\&4) (1986) 221-223

Singh, S.K., Syamal, M.M., Maurya, A.N., Effect of NAA and Ethrel on vegetative growth, flowering, fruiting and yield of cashew nut (Anacardium occidentale L.), The Cashew 6(2) (1992) 11-12

Skene, K G., Carr, D J., A quantitative study of the gibberellins content of seed of Phaseolus vulgaris at different stages in their development, Aust. J. Biol. Sci. 14 (1961)13-25

Stoew, B B., Tamaki, T., History and physiological actions of gibberellins, Ann. Rev. Plant Physiol. 8 (1957) 181-216

Subbaiah, C. C., comparative physiology of sun and shade leaves of cashew.-In proceedings of PLACROSYM-V. Indian Society for Plantation Crops, Kasargod (1984) 219-223

Sumiki, Y., Biochemistry of the Bakanae fungus. The Physiological action of gibberellins, J. Agric. Chem. Soc. 26 (1952) 393-397

Thimmappaiah., Shirly, R.A., Sadhana, P.H., In vitro propagation of cashew from young trees, In vitro cell. Dev. Biol. Plant 38 (2002) 152-156

Valdovinos, J G., In: Gibberellins and Plant Growth. (Ed. Krishnamoorthy, H N) Wiley, (1975) New Delhi

Veeraraghavathatham, D., Palaniswamy, 
K.P., Effect of certain growth regulators on the yield of cashew (Anacardium occidentale L.), Cashew Casuerie 3 (1983) 3-4

Wahdan, M T., Habib, S E., Bassal, M A., Qaoud, E M., Effect of some chemicals on growth, fruiting, yield and fruit quality of "Succary Abiad" mango cv. J. of American Sci. 7(2) (2011) 651-658

Went, F.W., A test method for rizhocaline, the root-forming substance, Proc. K. Ned. Akad. Wet. 37 (1934) 445-455

Yamdagni, R., and Khangia, B., Effect of growth regulators on enzyme activities in shoot tips at various stages of bud differentiation in mango (Mangifera indica L.) cv. S.B. Chausa, South Indian Horticulture 37(4) (1989) 194198

Zahoor, A. B., Rizwan, R., Javid, A.B., Effect of Plant Growth Regulators on Leaf Number, Leaf Area and Leaf Dry Matter in Grape, Not. Sci. Biol. 3(1) (2011) 87-90

Zoffoli, J.P., Latorre, B. A., Naranjo, P., Pre harvest application of growth regulators and their effect on postharvest quality of table grapes during cold storage, Post Harvest Bio. and Tech. 51 (2009) 183-192

\section{How to cite this article:}

Babli Mog, D. Adiga and Nayak, M.G. 2018. Role of Plant Growth Hormones in Cashew: Key Strategy for Modifying Crop Performance. Int.J.Curr.Microbiol.App.Sci. 7(07): 1470-1484. doi: https://doi.org/10.20546/ijcmas.2018.707.174 